\title{
THE SIGNIFICANCE OF ALIEN AND INVASIVE SLUG SPECIES FOR PLANT COMMUNITIES IN AGROCENOSES
}

\author{
Jan Kozłowski* \\ Institute of Plant Protection - National Research Institute \\ Władysława Węgorka 20, 60-318 Poznań, Poland
}

Received: June 28, 2011

Accepted: October 3, 2011

\begin{abstract}
This paper lists alien invasive species of slugs occurring on crops grown in the ground and under covers, as well as in adjacent habitats. It gives a description of their origin, distribution within Poland, frequency of occurrence in different habitats, and an evaluation of the danger to cultivated plants posed by particular slug species. Based on reports in the literature and the results of original research, basic data is presented concerning the biology and harmfulness of these slugs on crops. The potential risk of the spreading of invasive slug species is evaluated, as well as their adverse impact on crop plants. It has been concluded that a major risk to the biodiversity of agrocenoses and to cultivated plants is currently posed by the slugs Arion lusitanicus, A. rufus and A. distinctus. These slugs are spreading rapidly within Poland, often occur in large numbers, and do significant damage to various species of plant.
\end{abstract}

Key words: invasive slug species, distribution, harmfulness, risk to cultivated plants

\section{INTRODUCTION}

In recent years there has been an increase in the threat posed to Polish ecosystems by alien invasive species of fungi, plants and animals. Often the alien species cause irreversible changes in native populations and biocenoses. Intense growth in worldwide exchange of goods, intensification of transportation and tourism, and the use of new technologies in plant production have increased the spread. Of particular importance are the invasions of certain herbivores which form massive populations on new terrain. Such herbivores are often the cause of major crop yield losses. A large group among these consists of slugs (Gastropoda: Pulmonata), which in the last three decades have been spreading rapidly in Poland, similarly as in other countries of Europe (Reischütz 1984; Davies 1987; von Proschwitz 1992, 1994; von Proschwitz and Winge 1994; Frank 1998; Wiktor 2004; Kozłowski 2001, 2008; Kozłowski et al. 2008; Głowaciński et al. 2009; Stworzewicz and Kozłowski 2009).

According to the generally accepted definition, alien invasive species are understood to be those species whose introduction and/or spread poses a threat to biological diversity. These are species which have been carried by accident or deliberately from their natural biotope to the terrain of another country. Such invasive species are able to adapt to the new conditions, affect the environment through changes in the composition of native species, and cause economic losses or endanger the health of people and livestock. Invasive species also include those which rapidly and in large numbers colonize new areas and habitats and cause adverse effects in ecosystems and in the economy. These include both alien species and native species which increase the area and/or spectrum of their habitat (Głowaciński et al. 2009). Studies show the almost 800 alien species of plants, animals and fungi present in Poland include around 300 species of animal (Głowaciński et al. 2009). Around $40 \%$ of these species are considered invasive or scientifically and socially significant. Apart from vertebrates, these include species of various systematic groups of importance in plant production, such as insects, arachnids, nematodes and gastropods.

There are currently 177 species of land gastropods (Gastropoda: Pulmonata: Stylommatophora) occurring in Poland (Wiktor 2004). Around $10 \%$ of these are species alien to Poland's malacofauna. Some of these aliens can be considered invasive species (Stworzewicz 2008). In most cases, it is not known when and in what circumstances these aliens were introduced into Poland. Most of them live in anthropogenic environments, usually as synanthropes, and only certain species have spread additionally to semi-natural or natural environments (Riedel and Wiktor 1974; Riedel 1988; Wiktor 1973, 1987, 1989, 1996, 2004; Stworzewicz 2008). Some of the alien invasive species of gastropods, particularly slugs, have adapted to agrocenoses, where they are serious pests to plants (Kozłowski 1999, 2005, 2007, 2008).

The purpose of the present paper is to recapitulate information concerning invasive slug species occurring in Poland. The focus is on those which pose a particular threat to the biodiversity of native ecosystems and are pests or potential pests to crop plants. 


\section{MATERIALS AND METHODS}

A list of alien invasive species of slugs occurring on crops in open habitats and in greenhouses was drawn up. We used our own observations and of source materials contained in the publications of several Polish authors (Kosińska 1973; Riedel 1988; Riedel and Wiktor 1974; Wiktor 1973, 1989, 1996, 2001, 2004; Kozłowski and Kornobis 1994, 1995; Kozłowski 1999, 2008; Kozłowski et al. 2010; Stworzewicz 2008; Głowaciński et al. 2009). Studies concerning the distribution and occurrence of slugs were carried out between 1993 and 2010, at sites of slug occurrence. These were sites reported to the Institute of Plant Protection - National Research Institute in Poznań by the plant protection services, individual plant producers and owners of farms and gardens. At the reported sites, observations were made of different habitats in order to confirm or detect the occurrence of invasive slug species. From each locality, up to 20 specimens were collected. Following conservation, their species were determined by analysis of internal organs, according to the keys given by Riedel and Wiktor (1974) and Wiktor (2004). Detailed studies have been conducted for Arion lusitanicus, A. rufus and $A$. distinctus, species which are of great significance in agriculture and horticulture. Observations were made of the extent of damage done to various plant species to assess the effect of those slugs on plant health (Kozłowski 2008; Kozłowski and Kozłowski 2010).

\section{RESULTS}

Alien and invasive species of gastropods occurring at the present time on crop plants in Poland, include 19 species: nine snails and ten slugs (Table 1). Among the snails, a significant impact on crop plants is made by Monacha cartusiana and Zonitoides arboreus. M. cartusiana is regarded in some Mediterranean countries as a significant pest to plants growing in field (Mikovcová et al. 2007), while Z. arboreus damages ornamental plants growing in greenhouses, such as orchids and ferns (Barker and Efford 2004). So far in Poland, these two species have been identified only at a few sites, and no data is available on the damage caused by them. A third invasive species, Helicella obvia, relatively recently spread to cover almost the entire country (Wiktor 2004). H. obvia very often occurs in large numbers on various species of herbaceous plants and on decorative and orchard shrubs and trees. In spite of its numbers, plant damage caused by that snail has not been observed, and its effect on plants has not yet been determined.

Of much greater significance for plant communities in Poland are the invasive species of slugs. These include seven species living mainly in open environments $(A$. lusitanicus, A. rufus, A. distinctus, A. fasciatus, Tandonia budapestensis, Deroceras panormitanum and Boettgerilla pallens), two living in greenhouses and heated plastic tunnels (Lehmannia valentiana, Limax flavus), and one species (Limax maximus) which inhabits both environments (Table 1 ). The greatest impact on plant communities, and particularly on crop plants, comes from the slugs A. lusitanicus, A. rufus and $A$. distinctus, which are serious pests.

\section{Arion lusitanicus}

A. lusitanicus originates from the Iberian Peninsula. In the past half-century it has spread as an invasive species in most countries of western, central and northern Europe (Wiktor 2004; Kozłowski 2008; Stworzewicz and Kozłowski 2009). The occurrence of this slug in Poland was first documented in 1993 based on specimens found in Albigowa and Markowa near Łańcut (Kozłowski and Kornobis 1994, 1995). The slug spread very rapidly in the region of Rzeszów (in the south-eastern part of the country). After 1997, it could also be found in other regions

Table 1. The list of invasive species of snail and slug occurring in Poland

\begin{tabular}{|c|c|c|c|c|c|}
\hline \multicolumn{3}{|c|}{ Snails } & \multicolumn{3}{|c|}{ Slugs } \\
\hline species & family & habitat & species & family & habitat \\
\hline $\begin{array}{l}\text { Cernuella neglecta } \\
\text { (Draparnaud, 1805) }\end{array}$ & Helicidae & $\mathrm{OB}$ & $\begin{array}{l}\text { Arion distinctus } \\
\text { (Mabille, 1868) }\end{array}$ & Arionidae & OB \\
\hline $\begin{array}{l}\text { Helicella itala } \\
\text { (Linnaeus, 1758) }\end{array}$ & Helicidae & $\mathrm{OB}$ & $\begin{array}{l}\text { Arion fasciatus } \\
\text { (Nilsson, 1822) }\end{array}$ & Arionidae & $\mathrm{OB}$ \\
\hline $\begin{array}{l}\text { Helicella obvia } \\
\text { (Menke, 1828) }\end{array}$ & Helicidae & $\mathrm{OB}$ & $\begin{array}{l}\text { Arion lusitanicus } \\
\text { (Mabille, 1868) }\end{array}$ & Arionidae & OB \\
\hline $\begin{array}{l}\text { Helicodiscus singleyanus } \\
\text { (Pilsbry, 1889) }\end{array}$ & Endodontidae & $\mathrm{OB}$ & $\begin{array}{c}\text { Aroin rufus } \\
\text { (Linnaeus, 1758) }\end{array}$ & Arionidae & OB \\
\hline $\begin{array}{l}\text { Monacha cartusiana } \\
\text { (O.F. Müller, 1774) }\end{array}$ & Helicidae & $\mathrm{OB}$ & $\begin{array}{l}\text { Boettgerilla pallens } \\
\text { (Simroth, 1912) }\end{array}$ & Boettgerillidae & OB \\
\hline $\begin{array}{l}\text { Opeas pumilum } \\
\text { (L. Pfeiffer, 1840) }\end{array}$ & Subulinidae & GR & $\begin{array}{c}\text { Deroceras panormitanum }{ }^{\mathrm{P}} \\
\text { (Lessowa et Pollonera, } 1882 \text { ) }\end{array}$ & Agriolimacidae & OB \\
\hline $\begin{array}{l}\text { Oxychilus draparnaudi* } \\
\text { (Beck, 1837) }\end{array}$ & Zonitidae & $\begin{array}{l}\text { OB, GR, } \\
\text { SF }\end{array}$ & $\begin{array}{l}\text { Lehmannia valentiana } \\
\text { (Férussac, 1823) }\end{array}$ & Limacidae & GR \\
\hline $\begin{array}{l}\text { Oxychilus translucidus } \\
\text { (Mortillet, 1854) }\end{array}$ & Zonitidae & GR & $\begin{array}{c}\text { Limax flavus } \\
\text { (Linnaeus, 1758) }\end{array}$ & Limacidae & GR, SF \\
\hline \multirow[t]{2}{*}{$\begin{array}{l}\text { Zonitoides arboreus } \\
\text { (Say, 1816) }\end{array}$} & Gastrodontidae & GR & $\begin{array}{l}\text { Limax maximus } \\
\text { (Linnaeus, 1758) }\end{array}$ & Limacidae & GR, SF \\
\hline & & & $\begin{array}{c}\text { Tandonia budapestensis }{ }^{\mathrm{P}} \\
\text { (Hazay, 1881) }\end{array}$ & Milacidae & OB \\
\hline
\end{tabular}

"predatory snail, ${ }^{\mathrm{P}}$ potentially pest, $\mathrm{OB}$ - open biotopes, GR - greenhouses, SF - storage facilities 
of Poland also (Kozłowski 2001). At present, it occurs in nine provinces, chiefly in the south-eastern, central and western parts of the country (Fig. 1). New sites are constantly being identified, especially in southern regions (Kozłowski 2008; Kozłowski et al. 2008; Kozłowski and Kozłowski 2010).

A. lusitanicus is a slug with a length of $120 \mathrm{~mm}$ and a width of $18 \mathrm{~mm}$ when crawling. Most specimens reach a length of approximately $100 \mathrm{~mm}$. Some individuals can live for as long as two years, and then their length is approximately $140 \mathrm{~mm}$ (Davies 1987; Kozłowski 2000a, b). Eggs and young slugs overwinter, but only rarely do adults overwinter. Mating begins at the end of July, and eggs are laid from mid August to November. In a lifetime a slug lays $240-540$ eggs, 405 on average, in batches of between 12 and 124 eggs (Kozłowski 2000b, 2007; Kozłowski and Sionek 2000a). The eggs are spherical or oval, measuring $4.2 \times 3.5 \mathrm{~mm}$. Up to $30 \%$ of slugs hatch before winter, and the remainder the following spring (Kozłowski and Kozłowski 2000). In the vegetation season there are two peaks of numbers, the first in mid May, and the second - characterized by greater numbers - in the first half of August (Kozłowski 2000a; Kozłowski and Sionek 2000b).

A. lusitanicus inhabits areas of agricultural and garden cultivation, parks, and uncultivated land such as cemeteries, scrubland, rubbish dumps, rubble heaps, etc. It occurs most frequently in gardens and cultivated fields situated near buildings and watercourses, and in ditches, baulks, wasteland and scrubland, adjacent to areas of plant cultivation. The slug does damage to cultivated vegetables and ornamental, agricultural, orchard and herb plants (Kozłowski 2005, 2008; Kozłowski and Kozłowski 2010). It also grazes on various herbaceous plants growing wild on wasteland and scrubland near crops. Among agricultural plants, the greatest extent of damage has been identified on such plants as sunflowers (Helianthus annuus), potatoes (Solanum tuberosum) and Persian clover (Triforium resupinatum). On the edges of plantations of winter rape (Brassica napus ssp. napus) and winter wheat (Triticum aestivum), in the germination period, the slug caused an average of from 6 to $15 \%$ degree of damage to plants (Kozłowski 2008). Among vegetables, the greatest extent of damage was observed for seedlings of such plants as

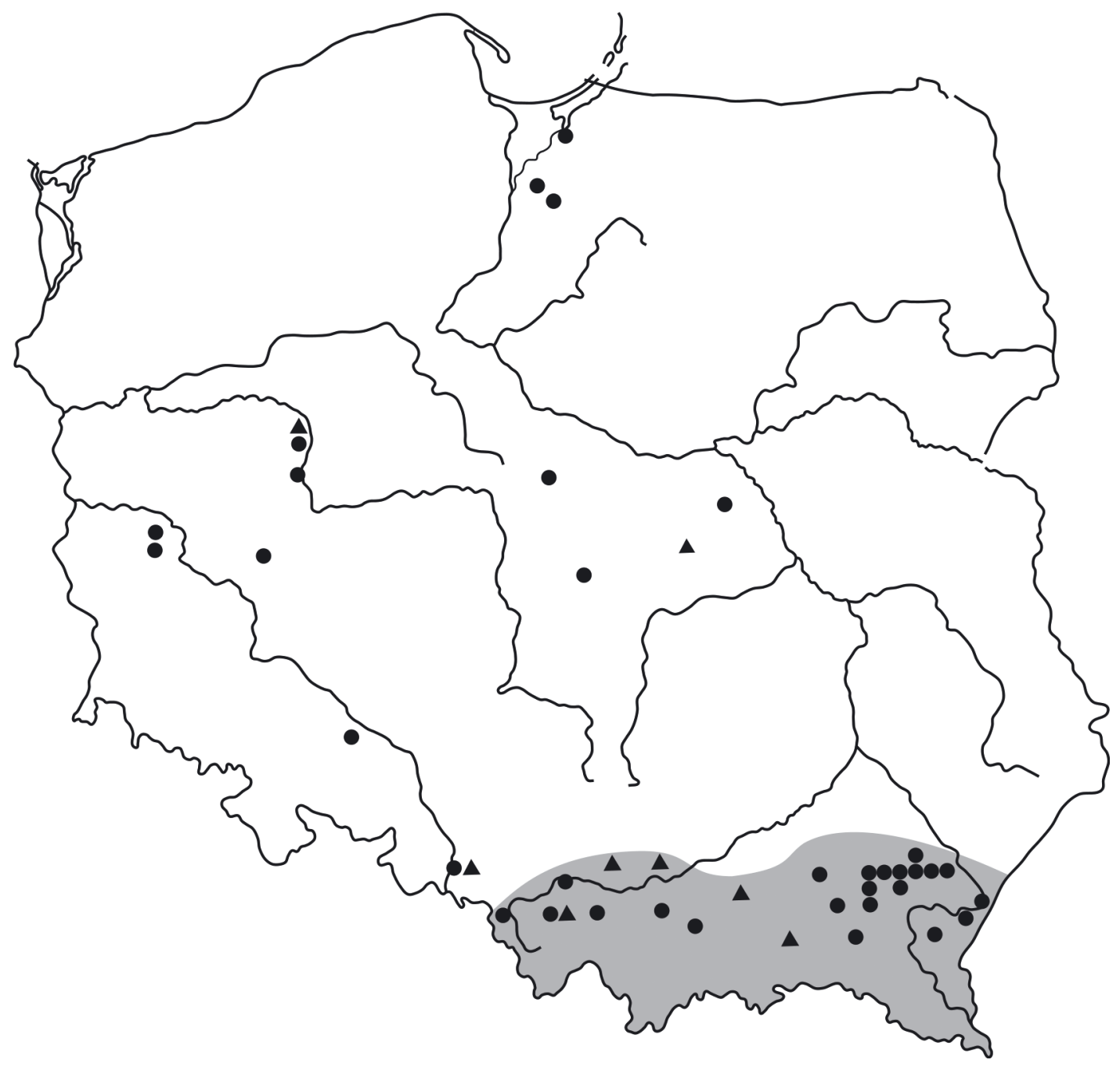

Colonized area (orig.), • Sites of discovered slugs in 1993-2008 (Kozłowski and Kozłowski 2010),

\ Sites of discovered slugs in 2009-2010 (orig.)

Fig. 1. Distribution of Arion lusitanicus in Poland 
lettuce (Lactuca sativa var. capitata), head cabbage (Brassica oleracea. var. capitata f. alba), Chinese cabbage (B. rapa ssp. pekinensis), beetroot (Beta vulgaris var. conditiva), carrot (Daucus carota ssp. sativus), parsley (Petroselinum crispum convar. radicosum) and bean (Phaseolus vulgaris var. na$n u s)$. Mature vegetable plants are also heavily damaged by $A$. lusitanicus particularly the leaves of cabbage and lettuce, leaves and roots of beetroot and carrots, and the leaves and pods of beans. The slugs gnaw out holes and drill channels in the roots of carrots and beetroot and the tubers of potatoes. Among orchard plants, the most frequently damaged are the fruits of strawberry and raspberry. Moreover, A. lusitanicus damages cultivated and wild-growing ornamental and herb plants such as $\mathrm{Al}$ thaea rosea, Archangelica officinalis, Dahlia variabilis, Lilium candidum, Ocimum basilicum, Rudbeckia laciniata, Tagates erecta, Zinnia elegans and others. It also damages some dicotyledonous weeds growing in baulks, ditches and scrubland, including Aegopodium podagraria and Urtica dioica (Kozłowski and Kozłowska 2000; Kozłowski 2008).

\section{A. rufus}

A. rufus is a western European species. It occurs mainly in western Europe, from the Pyrenees to the Alps, and in the central part of Europe (Riedel and Wiktor 1974; Wiktor 2004). It has also been carried to the US and Canada (Forsyth 2004). In northern Europe it inhabits the British Isles and Scandinavia (Anderson 2005). The northern boundary of its natural extent runs along the southern coasts of the Baltic. The first mention of the slug's occurrence in Poland dates from the mid 18th century, although only some of them have been confirmed by later investigations (Riedel and Wiktor 1974; Riedel 1988). Poland is on the eastern boundary of the natural extent of $A$. rufus (Riedel and Wiktor 1974). It is a native species in the west of the country, where it occurs in a strip from the southern border to the Baltic coast and the mouth of the Vistula. While in the Poznan region it extends to the Warta river. It can also be found in clusters in other regions of the country, for instance in Rzeszów and in locations to the south of Katowice and Kraków (Riedel and Wiktor 1974, Kozłowski and Kornobis 1995). In 2007-2009, new sites were discovered around Kępno and Łódź and in 2010 near Krzeczów (Kozłowski and Kozłowski 2010, Fig. 2).



Area of natural occurrence (Wiktor 2004), • Sites of discovered slugs in 1993-2008 (Kozłowski and Kozłowski 2010),

A Sites of discovered slugs in 2009-2010 (orig.)

Fig. 2. Distribution of Arion rufus in Poland 
This indicates that, like A lusitanicus, this slug is appearing in more and more new clusters, where it forms very numerous populations.

A. rufus reaches lengths of up to $150 \mathrm{~mm}$ and widths of $20 \mathrm{~mm}$, while crawling. It lives for about one year (Frömming 1954; Riedel and Wiktor 1974; Kozłowski 1999). A. rufus can overwinter in all stages of development, particularly in the egg stage. Mating begins in June and lasts until August (Frömming 1954). A small percentage mate in September and October. One individual lays an average of 415 eggs, in batches of between 20 and 250 eggs. The eggs are round or oval, measuring from 5.6x4.3 $\mathrm{mm}$. The slugs hatch in late summer and autumn, and in spring from eggs which have overwintered. The population of the slugs increases successively from spring until late summer. The first population peak occurs at the end of June, and the second at the end of September/beginning of October (Sionek and Kozłowski 1999). The high population is maintained almost until the middle of October.

A. rufus originally occurred in forests and in open biotopes, particularly in the vicinity of water bodies, and avoided developed environments. It occurred mainly on lowlands, and only in valleys of mountain areas and in low parts of the lower montane (Riedel and Wiktor 1974). At present it inhabits very varied biotopes, such as the banks of lakes, ponds and rivers, forests and scrubland, meadows, ditches, roadsides, cemeteries, parks and rubbish dumps, as well as agrocenoses. It is omnivorous, grazing on fungi, the excreta of various animals, carrion, and live and dead plants (Riedel and Wiktor 1974). It is now found more and more often in gardens and on the edges of areas of crops, such as winter rape and winter wheat. In these places, it occurs in very large numbers. This slug very often settles on compost and on vegetable remains, where it grazes readily on rotting and decomposing plants. Like A. lusitanicus, it does the greatest damage to crops of vegetables. It also damages some agricultural plants, flowers, perennial herbs, other herb plants and strawberries (Kozłowski and Kozłowski 2010). Among agricultural plants, the greatest extent of damage caused by the slug has been found for sugar beet plants (Beta vulgaris var. altissima), winter rape (B. napus ssp. napus), potato (S. tuberosum) and winter wheat (T. aestivum). Among vegetables the greatest extent of damage caused by this slug has been observed for root plants, particularly carrot (D. carota ssp. sativus) and parsley ( $P$. crispum convar. radicosum). Also heavily damaged by $A$. rufus are: beetroot (B. vulgaris var. conditiva), head cabbage (B. oleracea var. capitata), lettuce (L. sativa var. capitata) and common bean ( $P$. vulgaris var. nanus). This slug causes a high degree of damage to flower plants, particularly Callistephus chinensis, D. variabilis, Digitalis grandiflora, L. candidum, $R$. lacinata and Z. elegans, including damage to both their leaves and flowers. It also causes damage to some wild-growing plants such as Centaurea chinensis, Artemisia dracunculus, Conium maculatum, Papaver rhoeas, Taraxacum officinale and $U$. dioica (Kozłowski and Kozłowski 2010).

\section{A. distinctus}

A. distinctus is a Mediterranean-Atlantic species, probably originating from Western Europe. It has been carried to many countries of central and northern Europe, including Britain (Riedel 1988; Wiktor 2004; Glen et al. 1989; Iglesias and Speiser 2001), as well as the United States, Canada and New Zealand (Barker 1999; Forsyth 2004). For many years the slug was recorded under the shared name Arion "hortensis", as a coenospecies. The name Arion "hortensis" included three different species: A. (Kobeltia) hortensis Férussac, 1819, A. (Kobeltia) oweni Dawies, 1979 and A. (Kobeltia) distinctus Mabille, 1868. Studied specimens from Poland correspond to the form denoted $A$. distinctus, while the other listed species do not occur in Poland (Riedel and Wiktor 1974; Wiktor 2004). The first reports of the occurrence of this slug in Poland date from the second half of the 19th century, but these reports are not necessarily accurate, as the name A. hortensis was also applied to other species of other subgenera, such as Carinarion and Mesarion (Riedel 1988). Confirmed sites of occurrence of the occurrence of this slug are located in the western part of the country (Wiktor 1973, 2004). In 1994, clusters were found outside the western region of Poland: in Rzeszów and in Poznań (Kozłowski et al. 1996). After 2006, more clusters were found around Kęty and Oświęcim and in the region of Opole (Kozłowski and Kozłowski 2010, Fig. 3).

The slug is up to $35 \mathrm{~mm}$ long when crawling. It can live for 7 to 16 months (Frömming 1954). Most individuals have a one-year life cycle, while a few have a twoyear cycle (Hunter 1966). They overwinter in all stages of development, chiefly in the egg stage. The slugs mate in April and at the end of summer, eggs are laid after 2-4 weeks. One slug lays up to 200 eggs, in batches of 10-80 eggs. The diameter of the eggs are $2.0-3.5 \mathrm{~mm}$ and they hatch after 20-40 days. The slugs hatch in June and July, and a few in late autumn or the following spring. The species occurs in large numbers from September until the end of October, with the population peaking at the end of September.

This slug lives as a synanthrope, mainly in habitats degraded by human activity, such as gardens, parks, cemeteries, rubbish dumps and rubble heaps. It can also be found in forests and scrubland, and in greenhouses. It is increasingly common on crops of garden and agricultural plants, where it forms very large populations and causes damage to plants (Kozłowski and Kozłowski 2010). It does great damage to crops of vegetables, particularly head cabbage (B. oleracea var. capitata $f$. alba), lettuce (L. sativa var. capitata), beetroot (B. vulgaris var. conditiva) and horseradish (Armoracia lapathifolia). It also causes damage to various species of papilionoids and to the fruits of wild and garden strawberries. In recent years, it has been increasingly common to observe these slugs on crops of winter rape (B. napus ssp. napus). In some places in fields, the number of specimens found per square metre has reached several dozen - or even around 100. In such places, $A$. distinctus damaged up to $25 \%$ of germinating rape plants (Kozłowski and Kozłowski 2010). Apart from winter rape, significant damage to plants has also been observed in crops of sunflowers (H. annuus), potato 




Colonized area (Wiktor 2004), • Sites of discovered slugs in 1993-2008 (Kozłowski and Kozłowski 2010), A Sites of discovered slugs in 2009-2010 (orig.)

Fig. 3. Distribution of Arion distinctus in Poland

(S. tuberosum), Persian clover (T. resupinatum) and maize (Zea mays). A. distinctus is very immobile and grazes almost exclusively at night. For this reason it is a threat chiefly to crop plants where there are a sufficiently large number of available hiding places (stones, plant remains, pieces of wood, etc.) in the vicinity. Like Deroceras reticulatum, a common pest in Poland (O.F. Müller, 1774), A. distinctus may also be found in the inner parts of fields. If it finds hiding places in the form of lumps or cracks in the soil, it will hide and find shelter there during the day. Apart from agricultural and vegetable plants, this slug also attacks various species of flowers (e.g. D. variabilis, Z. elegans) and dicotyledonous weeds such as T. officinale, particularly its flowers, and Arctium lappa, Chenopodium album, Galinsoga praviflora and $U$. dioica.

\section{A. fasciatus}

A. fasciatus has spread through many countries of central, western and northern Europe, although its origin is not known. In Poland, it was recorded in the 1970s, and at present occurs as a synanthrope, in all parts of the country (Wiktor 1973, 2004; Riedel and Wiktor 1974). It can be found in parks, cemeteries, rubbish dumps and ruined buildings, as well as in gardens, where it sometimes causes damage to plants. This slug is very immobile and often lives in hiding places in the soil and under plant remains or other objects lying on the soil surface. The damage done to crop plants by this slug is of an incidental nature and is not extensive.

\section{T. budapestensis and D. panormitanum}

T. budapestensis and D. panormitanum are in a phase of expansion, spreading as synanthropes in many countries of central and northern Europe (Bössneck 1994), in the United States (Reise et al. 2006) and in other parts of the world. They occur in forests, parks, gardens, greenhouses, in crop fields, particularly in the vicinity of rivers, streams and water bodies, and in stores of vegetables and fruit. In some plantations of garden and agricultural plants they cause significant damage (Port and Port 1986; Glen et al. 1992; Davis 1989). T. budapestensis probably originates from subalpine areas and the south of Europe. In western Europe, it is a serious pest to plants, particularly potatoes, root plants and some flowers (van den 
Bruel and Moens 1958; Godan 1979, 1983; South 1992). In Poland, it has been identified at two synanthropic sites, in Cieszyn and Wrocław (Kosińska 1973; Wiktor 1973, 1989). D. panormitanum, formerly called Deroceras caruanae (Pollonera, 1991), originates from the Mediterranean region (Wiktor 2000). It is a pest to cultivated plants in pastures, nurseries, greenhouses and gardens. It does damage to commercial crops such as asparagus and lettuce (Castillejo et al. 1996; Barker 1999). In Poland, it has so far been found at one site in Wrocław (Wiktor 2000, 2001, 2004). In view of the high level of damage which can be caused by these two slug species, they may pose a future threat to cultivated plants in Poland.

\section{L. maximus}

L. maximus probably originates from south-western Europe (Wiktor 1989, 2004) and possibly from southern Africa and Asia Minor (Barker 1999). As a synanthrope, it has been carried to many parts of the world. It occurs throughout Poland, but only in the vicinity of buildings. It lives in parks, gardens, rubbish dumps, glasshouses, cellars, and warehouses and other stores of fruit and vegetables. It is very much a nocturnal slug. It shelters and overwinters in cellars, canals, wells and compost heaps. It eats fungi, carrion, and fresh and rotting plants (Barker 1999). It causes damage to plants grown in the soil and under covers, as well as in storage. This includes the leaves, fruit, tubers and roots of various species of vegetables. It also damages some ornamental plants, particularly perennial herbs and bulb flowers. It does not occur in large groups, but because of its large body size it can cause a significant degree of damage to garden plants. It is very aggressive in relation to other slug species, and may be cannibalistic (Gordon 1994).

\section{L. flavus and L. valentiana}

L. flavus probably originates from south-eastern Europe and Asia Minor. It has spread as a synanthrope throughout Europe, in Africa and Australia, and on oceanic islands. It occurs in all parts of Poland (Wiktor 1989, 2004). L. valentiana is a native species to the Iberian Peninsula and probably north-western Africa (Wiktor 1989, 2004). It has been carried to many countries of western Europe, North and South America, and the islands of the Atlantic and the Pacific. In Mediterranean countries, it occurs commonly in field conditions. In Poland, it has been found at several sites in greenhouses and gardens (Wiktor 2004). Both species are warmth-loving and occur in Poland in greenhouses and in damp cellars, homes, warehouses and stores. They cause damage to vegetables, fruit and ornamental plants. They eat the green parts of plants as well as tubers and roots. L. flavus is very much a nocturnal slug. It eats fungi, lichens, vegetables and rotting plant material, and often occurs in large numbers. L. valentiana most often causes damage on flower plants in greenhouses, particularly hydroponic crops, where the damage may be very significant. It also attacks such plants as alstroemeria, anthurium, aster, begonia, cyclamen, zinnia, dieffenbachia, gerbera, hypoestes, orchid, scindapsus and others (Dankowska 1991; South 1992). It is sometimes accompanied by the marsh slug Deroceras laeve (O.F. Müller, 1774) on covered crops, where plants are damaged by both species together. In Britain, it is a pest to plants cultivated in gardens (Kerney and Cameron 1979). The occurrence of L. flavus and L. valentiana in Poland is local in nature. Therefore, their significance as pests to plants is not great at the present time.

\section{B. pallens}

B. pallens originates from the western Caucasus (Georgia). In the 1940s it was carried to central Europe, and since then it has spread almost to the whole of Europe. It was first identified in Poland in 1959 (Riedel 1988; Wiktor 2004). It occurs in the south of the country, mainly in synanthropic environments such as rubbish dumps, rubble heaps, parks and gardens, and in forests of natural character. No plant damage caused by this slug has yet been observed. Its diet is not known. It is in a phase of expansion, and the species can be expected to spread all over Europe and throughout the whole of Poland.

\section{DISCUSSION}

Invasive species of land gastropods are examples of animals which can very easily be carried or migrate to new environments. Some of the gastropods rapidly adapt to the new conditions, sometimes forming very large populations. Species such as A. lusitanicus, A. rufus and A. distinctus have become serious pests to plants. Grazing by these slugs leads to economic losses connected with reduction in crop yields and the need to incur direct and indirect costs in order to combat them. This applies, above all, to A. lusitanicus, which was carried to Poland at the end of the 1980s (Kozłowski and Kornobis 1994, 1995; Sionek 2006). This slug has successfully adapted in many places in Poland. In recent years its spread has increased at a very fast rate, such that the species now occurs in nine provinces (Kozłowski 2008; Kozłowski et al. 2008, Soroka et al. 2009). A. lusitanicus forms very large populations in habitats of various plant communities, particularly on garden and agricultural crops, where it causes serious damage (Kozłowski 2005, 2007, 2008). The rapid rate of spread of this slug and its occurrence in mass numbers have also been observed in Austria (Reischütz 1984), Britain (Davies 1987), Sweden, Norway (von Proschwitz 1992, 1994; von Proschwitz and Winge 1994), and Switzerland (Frank 1998), where like in Poland. A. lusitanicus colonized very large areas over $15-20$ years. Due to its occurrence in large numbers in certain habitats, A. lusitanicus has become an ecological and economic problem both in Poland and in other European countries (Głowaciński et al. 2009).

Some authors take the view that the generally applied species name A. lusitancus should not be used for slugs occurring in central and northern Europe (Falkner et al. 2002; Anderson 2005). These taxa differ in terms of spermatophores and certain features of internal structure from the topotypes of lusitanicus sensu Mabille, from Setbol, Serra da Arrábida, Portugal (Castillejo and Roedriquez 1993; Castillejo 1997). It has therefore been proposed that the taxa occurring in central and northern Europe be given the name "vulgaris" Moquin-Tandom, 
1855; their original name, which was used for the first time by Altena (1955). That would mean that the slugs occurring in Poland now referred to as A. lusitanicus, would take the name A. vulgaris Moquin-Tanddon, 1855. However, this theory would need to be confirmed by molecular studies, investigating the genetic differences between the Polish and Portuguese taxa.

Observations show that slugs A. rufus and A. distinctus are being found more and more often in new clusters outside the area in the western part of the country which they have already colonized (Kozłowski and Kozłowski 2010). They pose a serious problem in synanthropic habitats degraded by human activity, particularly on garden and agricultural crops. Like $A$. lusitanicus these slugs do damage to various agricultural and vegetable plants. The probability of their moving to other places is very high, as is demonstrated by the appearance of new sites (Figs. 2 and 3). Although they do not feed as intensely or rapidly as A. lusitanicus, particularly in the case of $A$. rufus (own data, unpublished), the damage they cause to crops of certain plant species are economically significant. We have observed an example of this on germinating plants of winter wheat on the edges of fields, by A. rufus and to those of winter rape, by $A$. distinctus in some parts of fields (Kozłowski and Kozłowski 2010). Plant damage caused by these slugs has also been found on some vegetables and flowers, although the number of plantations attacked is much smaller than in the case of $A$. lusitanicus. Moreover, some authors note that $A$. distinctus penetrates to certain semi-natural environments (Stworzewicz 2008), where it may well damage the plants growing there. Natural habitats, such as leafy and mixed forests, are often colonized by A. rufus (Riedel and Wiktor 1974; Wiktor 2004). In these habitats we have observed the damage this slug has caused to various species of herbaceous plants.

Of lesser significance for crop plants is A. fasciatus, which occurs as a synanthrope on certain crops (Riedel and Wiktor 1974; Kozłowski 1999; Wiktor 2004), although the damage it causes is not great. No plant damage has yet been identified in the case of the invasive slug B. pallens, which spreads as a synanthrope mainly in degraded environments and can sometimes be found in gardens (Riedel 1988; Riedel and Wiktor 1974; Wiktor 2004). This slug has also penetrated to natural environments, and at present occurs in some forest reserves in the south of the country (Wiktor 2004; Stworzewicz 2008).

On garden and agricultural crops, particularly close to buildings, and in fruit and vegetable stores and warehouses, plant damage is sometimes caused by L. maximus (Kozłowski 1999; Wiktor 2004). This slug does not occur in mass numbers, which means that the damage it does is usually local in nature and relates to single plants. The species has colonized the whole area of the country. Its numbers can be expected to increase on some crops, particularly during periods of heavy rainfall and high soil and air humidity.

L. valentiana and L. flavus, which occur on greenhouse and covered crops and in vegetable and fruit stores, cause damage to flower and vegetable plants (Dankowska 1991; South 1992; Wiktor 1989, 2004). The extent of the damage done by these slugs in Poland has not been studied in de- tail. Both species occur locally in some greenhouses and heated tunnels, and may spread to new places together with plant material. Some authors place L. flavus among the invasive animal species which are capable of dominating native populations and biocenoses (Głowaciński et al. 2009).

A potential threat to crop plants is posed by the invasive slugs T. budapestensis (Kosińska 1973; Wiktor 1989, 2004) and D. panormitanum (Wiktor 2000, 2001, 2004), which have been found at a few sites in Poland. These slugs are spreading in many countries of central and northern Europe (Bössneck 1994), where they are serious pests to vegetables and flowers (van den Bruel and Moens 1958; Castillejo et al. 1996; Godan 1979, 1983; South 1992; Barker 1999). With the progressive warming of the climate in Poland, they may become serious future pests to plants growing in the field. Another potential pest may be Krynickillus melanocephalus (Agriolimacidae), originating from the northern Caucasus, but not yet recorded in Poland. Synanthropic populations of this slug occur in the Erfurt region of Germany and in Riga. In these places, it causes serious damage to cultivated plants (Wiktor 2000).

The invasive slug species which are spreading in Poland, such as A. lusitanicus, exert a significant effect on plant communities because they cause excessive damage to certain plant species. Such damage leads to significant depletion of those species or changes in the species composition. An example of this, is the destruction of A. podagraria plants by A.lusitanicus (Kozłowski and Kozłowska 2000; Kozłowski 2008), observed in Łańcut and surrounding areas. The degree of damage to plants of this species has been found to be so great that in the summer, in places where the slug occurs in large numbers, the weed is almost entirely absent. Over a period of several years, it has been replaced by plants of the genera Impatiens, Potentilla and Epilobium, which are not eaten by A. lusitanicus. Changes in the species composition of plants under pressure of grazing by this slug, have also been observed by other authors (Keller et al. 1999; Frank 2003; Buschmann et al. 2005; Lanta 2007). These observations prove that selective grazing by $A$. lusitanicus on particular plant species may alter the species composition of plant communities in natural and anthropogenic habitats.

It has been found that during colonization and adaptation to new habitats, A. lusitanicus may replace other gastropod species occurring there by forming very large populations and competing for food and living space. This has been observed in gardens in Rzeszów, where A. rufus was present in 1993-1998, but where after 2002 it was completely replaced by A. lusitanicus (author's observations, unpublished). L. maximus is another example of a very aggressive slug which attacks other gastropod species, causing reduction in their numbers (Gordon 1994). Such behaviour by invasive slug species, the absence of natural enemies, the abundance of food, and suitable living places as well as favourable climatic conditions, undoubtedly facilitate the colonization of new habitats by these creatures.

With the globalization of trade and tourism, and the intensification of and changes in plant production, and particularly as a result of the growth in exchange of plant 
materials, the problem of invasion and spread of alien gastropod species in agrocenoses will intensify. It is therefore, necessary to carry out monitoring of invasive slug species, track the changes occurring in their populations, and record the species which are brought into the country. The main goal of future research will be to determine the possibility of expansion by invasive slug species in Polish climatic conditions, and to assess the threats they may pose to the biodiversity of agricultural environments and to plant production.

\section{ACKNOWLEDGEMENTS}

This project was supported by the National Center for Science, Poland, contract No. 7350/B/PO1/2011/40

\section{REFERENCES}

Altena C.O. van Regteren. 1955. Notes sur les Limaces. 3. Sur la présence en France d'Arion lusitanicus Mabille, 1868. J. de Conchyl. 95 (3): 89-99.

Anderson R. 2005. An annotated list of the non-marine Mollusca of Britain and Ireland. J. Conch. 38 (6): 607-637.

Barker G.M. 1999. Naturalised Terrestrial Stylommatophora (Mollusca: Gastropoda). Fauna of New Zealand 38, 254 pp.

Barker G. M., Efford M. G. 2004. Predatory gastropods as natural enemies to terrestrial gastropods and other invertebrates. p. 279-403. In: "Natural Enemies of Terrestrial Molluscs" (G.M. Barker, ed.). Landcare Res. Ham. New Zealand, CABI Publishing, Wallingford (UK) - Cambrige (USA) 1, $640 \mathrm{pp}$.

Bössneck U. 1994. Deroceras panormitanum (Lessona and Pollonera, 1882) und Tandonia budapestensis (Hazay, 1881) - zwei für Ostdeutschland neue Nacktschneckenarten (Gastropoda: Stylommatophora: Agriolimacidae et Milacidae). Staatliches Museum für Tierkunde Dresden 17: 87-90. (with English Summary).

Buschmann H., Keller M., Porret N., Dietz H., Edwards P. J. 2005. The effect of slug grazing vegetation development and plant species diversity in an experimental grassland. Funct. Ecol. 19: 291-298.

Castillejo J. 1997. The slugs of the family Arionidae Gray, 1840 from Iberia Peninsula and Balearic Islands. Morphology and distribution (Gastropoda, Pulmonata, Terrestria nuda). Rev. R. Acad. Galega Cien. 16: 51-118.

Castillejo J., Rodriquez T. 1993. Las especies del genero Arion Ferussac, 1819 en Portugal (Gastropoda, Pulmonata: Arionida). Graellsia 49: 17-37. (with English Abstract).

Castillejo J., Seijas I., Villoch F. 1996. Slug and snail pests in Spanish crops and their economical importance. p. 327-332. In: "Slug and Snail Pests in Agriculture" (I.F. Henderson, ed.). British Crop Protection Council, Monograph 6, Farnham, UK, 450 pp.

Dankowska E. 1991. Biologia i szkodliwość ślimaków nagich w szklarni i tunelu. Materiały 31. Sesji Nauk. Inst. Ochr. Roślin, cz. 2, 36-38. (with English Summary).

Davis A. J. 1989. Effects of soil compaction on damage to wheat seeds by three pest species of slug. Crop Protect. 8: 118-121.

Davies S. M. 1987. Arion flagellus Collinge and A. lusitanicus Mabille in the British Isles: A morphological, biological and taxonomic investigation. J. Conch. 32: 339-354.
Falkner G., Ripken T.E.J., Falkner M. 2002. Mollusques continentaux de France Liste de Référence annotée et Bibliographie. Patrimoines Natureles 52. Museum d'Histoire Naturelle, Paris, 350 pp.

Forsyth R.G. 2004. Land Snails of British Columbia. Royal British Columbia Museum, Canada, 188 pp.

Frank T. 1998. Slug damage and numbers of the slug pests, Arion lusitanicus and Deroceras reticulatum in oilseed rape grown beside sown wildflower strips. Agric. Ecos. Env. 67 (1): 67-78.

Frank T. 2003. Influence of slug herbivory on the vegetation development in an experimental wildflower strip. Basic Appl. Ecol. 4: 139-147.

Frömming E. 1954. Biologie der Mitteleuropäischen Landgastropoden. Berlin-München, 404 pp.

Glen D. M., Milson N. F., Wiltshire C. W. 1989. Effects of seedbad conditions on slug numbers and damage to winter wheat in a clay soil. Ann. Appl. Biol. 115: 177-190.

Glen D. M., Wiltshire C. W., Milsom N. F. 1992. Some aspects of forecasting slug damage in arable crops. J. Medical Appl. Malacol. 4: 147-152.

Głowaciński Z., Okarma H., Pawłowski J., Solarz W. 2009. Księga Gatunków Obcych Inwazyjnych w Faunie Polski. www. iop.krakow.pl/gatunkiobce

Godan D. 1979. Schadschnecken und ihre Bekämpfung. Ulmer: Stuttgart, $467 \mathrm{pp}$.

Godan D. 1983. Pest Slugs and Snails: Biology and Control. Springer-Verlag. Berlin, Germany, 445 pp.

Gordon D.G. 1994. Western Society of Malacologists Field Guide to the Slug. Sasquatch Books. Seattle, Waschington, $48 \mathrm{pp}$.

Hunter P.J. 1966. The distribution and abundance of slugs on an arable plot in Northumberland. J. Anim. Ecol. 35: 543-557.

Iglesias J., Speiser B. 2001. Distribution of Arion hortensis s.s. and Arion distinctus in Northern Switzerland. J. Moll. Stud. 67: 209-214.

Keller M., Kollmann J., Edwards P. J. 1999. Palatability of weeds from different European origins to the slugs Deroceras reticulatum Müller and Arion lisitanicus Mabille. Acta Oecologica 20: 109-118.

Kerney M. P., Cameron R. A. D. 1979. A Field Guide to the Land Snails of Britain and North-west Europe. Harper Collins Publish, London, 288 pp.

Kosińska M. 1973. Monacha cartusiana (Müller) i Milax budapestensis (Hazay) - dwa interesujące gatunki w faunie Polski. Przegl. Zool. 17: 59-62. (with English Summary).

Kozłowski J. 1999. Ślimaki (Gastropoda: Stylommatophora) niedoceniane szkodniki roślin uprawnych $\mathrm{w}$ Polsce. Post. Nauk Rol. 6: 39-50. (with English Summary).

Kozłowski J. 2000a. Distribution and places of occurrence of the slug Arion lusitanicus Mabille (Gastropoda: Pulmonata: Arionidae). Bull. Pol. Acad. Scien., Biol. Scien. 48 (4): 409-415.

Kozłowski J. 2000b. Reproduction of Arion lusitanicus Mabille, 1868 (Gastropoda: Pulmonata: Arionidae) introduced in Poland. Folia Malacol. 8 (1): 87-94.

Kozłowski J. 2001. A new site of occurrence of Arion lusitanicus Mabille, 1868 (Gastropoda: Pulmonata: Arionidae). J. Plant Protection Res. 41 (3): 309-313.

Kozłowski J. 2005. Host plants and harmfulness of the Arion lusitanicus Mabille, 1868 slug. J. Plant Protection Res. 45 (3): 221-233. 
Kozłowski J. 2007. The distribution, biology, population dynamics and harmfulness of Arion lusitanicus Mabille, 1868 (Gastropoda: Pulmonata: Arionidae) in Poland. J. Plant Protection Res. 47 (3): 219-230.

Kozłowski J. 2008. Obcy inwazyjny ślimak nagi ślinik luzytański - Arion lusitanicus. Charakterystyka, metody zwalczania i rejestracji stanowisk występowania w Polsce. Rozpr. Nauk. Inst. Ochr. Roślin 17, 48 pp.

Kozłowski J., Kałuski T., Jaskuska M. 2010. Obce inwazyjne gatunki ślimaków zagrażajace roslinom uprawnym w Polsce. Prog. Plant Protection/Postępy Ochr. Roślin. 50 (1): 133 139. (with English Summary).

Kozłowski J., Kałuski T., Kozłowski R. J. 2008. Rozmieszczenie i ekspansja populacji ślinika luzytańskiego (Arion lusitanicus Mabille) na terenie Polski. Prog. Plant Protection/Postępy Ochr. Roślin 48 (3): 893-897. (with English Summary).

Kozłowski J., Kornobis S. 1994. Arion sp. (Gastropoda: Arionidae) - szkodnik zagrażający roślinom uprawnym w województwie rzeszowskim. Materiały 34. Sesji Nauk. Inst. Ochr. Roślin cz. 2: 237-240. (with English Summary).

Kozłowski J., Kornobis S. 1995. Arion lusitanicus Mabille, 1868 (Gastropoda: Arionidae) w Polsce oraz nowe stanowisko Arion rufus (Linnaeus, 1758). Przegl. Zool. 39 (1-2): 79-82. (with English Summary).

Kozłowski J., Kozłowska M. 2000. Weeds as a supplementary or alternative food for Arion lusitanicus Mabille (Gastropoda: Stylommatophora). J. Conch. 37 (1): 75-79.

Kozłowski J., Kozłowski R. J. 2000. Periods of occurrence and fecundity of Arion lusitanicus Mab. (Gastropoda: Pulmonata) in crop plant habitats in Poland. J. Plant Protection Res. 40 (3/4): 260-266.

Kozłowski J., Kozłowski R.J. 2010. Obce Inwazyjne Gatunki Ślimaków Nagich Występujące w Polsce. Metody Wykrywania i Zapobiegania ich Rozprzestrzenianiu. Inst. Ochr. Roślin - PIB, Poznań, 60 pp.

Kozłowski J., Sionek R. 2000a. The rate of egg laying and hatching of the slug Arion lusitanicus Mabille, a pest of arable crops. J. Plant Protection Res. 40 (2): 162-167.

Kozłowski J., Sionek R. 2000b. Seasonal fluctuations of abundance and age structure of Arion lusitanicus Mabille, 1868 (Gastropoda: Pulmonata: Arionidae). Folia Malacol. 8 (4): 271-276.

Kozłowski J., Sionek R., Kozłowska M. 1996. Ocena przydatności różnych przynęt do odłowu ślimaków 'nagich' (Gastropoda: Stylommatophora). Prog. Plant Protection/Post. Ochr. Roślin 36 (2): 18-22. (with English Summary).

Lanta V. 2007. Effect of slug grazing on biomass production of a plant community during a short term biodiversity experiment. Acta Oecologica 32: 145-151.

Mikovcová A., Jứićková L., Petrusek A. 2007. Monacha cartusiana (O.F. Müller, 1774) - the phylogenetic study of the Central Europe populations has started. Abstracts of Invasive Molluscs Conference, Cambridge, 2 April 2007. The London Malacological Society, p. 9.

Port C. M., Port G. R. 1986. The biology and behaviour of slugs in relation to crop damage and control. Agric. Zool. Rev. 1: 255-299.

Reise H., Hutchinson J. M. C., Robinson D. G. 2006. Two introduced pest slugs: Tandonia budapestensis new to the Americas and Deroceras panormitanum new to the Eastern USA. The Veliger 48 (2): 110-115.
Reischütz P. L. 1984. Zum massenhaften Auftreten von Arion lusitanicus Mabille in den Jahren 1982 und 1983. Mitteilungen der Zoologischen Gesellschaft Braunau 4: 253-254.

Riedel A. 1988. Ślimaki Lądowe. Gastropoda terrestria. Katalog Fauny Polski 36, T. 1, 316 pp.

Riedel A., Wiktor A. 1974. Arionacea - Ślimaki Krążałkowate i Ślinikowate (Gastropoda: Stylommatophora). Fauna Polski 2. PWN, Warszawa, 140 pp.

Sionek R. 2006. Ślimaki. www.sionekr.republika.pl

Sionek R., Kozłowski J. 1999. Species composition and abundance dynamics of slugs (Gastropoda Terrestria Nuda) in urban conditions. Folia Malacol. 7 (2): 115-122.

Soroka M., Kozłowski J., Wiktor A., Kałuski T. 2009. Distribution and genetic diversity of the terrestrial slugs Arion lusitanicus Mabille, 1868 and Arion rufus (Linnaeus, 1758) in Poland based on mitochondrial DNA. Folia Biol. 57 (1-2): 71-81.

South A. 1992. Terrestrial Slugs: Biology, Ecology, and Control. Chapman and Hall, London, 444 pp.

Stworzewicz E. 2008. Obce gatunki ślimaków lądowych (Gastropoda terrestria) $\mathrm{w}$ polskiej malakofaunie - propozycje do „Księgi gatunków obcych inwazyjnych w Polsce”. XXIV Krajowe Seminarium Malakologiczne. Gdynia, 2-4 April 2008, p. 67.

Stworzewicz E., Kozłowski J. 2009. Arion lusitanicus Mabille, 1868 - ślinik luzytański. In: „Księga Gatunków Obcych Inwazyjnych w Faunie Polski" (Z. Głowaciński, H. Okarma, J. Pawłowski, W. Solarz, eds.). www.iop.krakow.pl/ gatunkiobce

van den Bruel W. E., Moens R. 1958. Remarques sur les facteurs écologiques influencant l'efficacité de la lutte contre les limaces. Parasitica 14: 135-147.

von Proschwitz T. 1992. Spanska skogssnigeln - Arion lusitanicus Mabille - en artisnabb spridning med människan i sverige. Göteborgs Naturhistorika Museum, Ärstryck: 35-42.

von Proschwitz T. 1994. Oxychilus cellarius (Müller) and Oxychilus draparnaudi (Beck) as predators on egg-clutches of Arion lusitanicus Mabille. J. Conch. 35 (2): 183-184.

von Proschwitz T., Winge K. 1994. Iberia skogsnegl - en art pä spredning i Norge (Arion lusitanicus Mabille - an anthropochorous slug spreading in Norway). Fauna. 47 (3): 195-300. (with English Summary)

Wiktor A. 1973. Die Nacktschnecken Polens - Arionidae, Milacidae, Limacidae (Gastropoda, Stylommatophora). Monogr. Fauny Polski 1, Warszawa-Kraków, 289 pp.

Wiktor A. 1987. Milacidae (Gastropoda, Pulmonata) - systematic monograph. Ann. Zool. 41 (3): 153-319.

Wiktor A. 1989. Limacoidea et Zonitoidea nuda. Ślimaki Pomrowiokształtne (Gastropoda: Stylommatophora). Fauna Polski - Fauna Poloniae 12, PWN Warszawa, 208 pp.

Wiktor A. 1996. The slugs of the former Yugoslavia (Gastropoda terrestria nuda - Arionidae, Milacidae, Limacidae, Agriolimacidae). Ann. Zool. 46: 1-110.

Wiktor A. 2000. Agriolimacidae (Gastropoda: Pulmonata) a systematic monograph. Ann. Zool. 49 (4): 155-157.

Wiktor A. 2001. Deroceras (Deroceras) panormitanum (Lessona et Pollonera, 1882) - a new introduced slug species in Poland (Gastropoda: Pulmonata: Agriolimacidae). Folia Malacol. 9 (3): 155-157.

Wiktor A. 2004. Ślimaki Lądowe Polski. Mantis, Olsztyn, 302 pp. 